\title{
Selective Proliferation of Lactic Acid Bacteria and Accumulation of Lactic Acid during Open Fermentation of Kitchen Refuse with Intermittent pH Adjustment
}

\author{
Kenji SaKaI, ${ }^{1}$ Yoshihiro Murata, ${ }^{2}$ Hiroshi YamaZumI, ${ }^{2}$ Yuko Tau, ${ }^{1}$ Masatsugu MorI, ${ }^{1}$ Mitsuaki MoriGuCHI ${ }^{1}$ \\ and Yoshihito SHIRAI ${ }^{2}$ \\ 'Department of Applied Chemistry, Faculty of Engineering, Oita University, Oita, Japan \\ ${ }^{2}$ Department of Biochemical Engineering, Faculty of Computer Science and System Engineering, Kyushu Institute of Technology, Fukuoka, Japan
}

Received December 16, 1999; Accepted February 29, 2000

\begin{abstract}
When minced and autoclaved model kitchen refuse was inoculated with a small amount of non-autoclaved model kitchen refuse as seed culture, incubated at $37^{\circ} \mathrm{C}$ for 3-5 days and intermittently $\mathrm{pH}$ neutralized, $27-45 \mathrm{~g} / \mathrm{l}$ of lactic acid was accumulated with a small amount of acetic acid and ethanol. The highest accumulation and highest productivity levels of lactic acid were observed at an initial and adjusted $\mathrm{pH}$ of 7.0 and a $6 \mathrm{~h}$ interval of pH adjustment. After several hours of lag, the lactic acid bacteria became the dominant cell type during the incubation, while the number of coliform bacteria and clostridia decreased. Such selective and stable accumulation of lactic acid was achieved in dozens of different experiments with various refuse preparations. In contrast, with continuous pH adjustment, lactic acid once accumulated was labile and a small amount of butyric acid was produced, increasing the number of clostridia. The dominant bacteria isolated from the fermentation with intermittent $\mathbf{p H}$ adjustment were identified as Lactobacillus plantarum and L. brevis.
\end{abstract}

Keywords: lactic acid, kitchen refuse, open fermentation, Lactobacillus plantarum, Lactobacillus brevis, $\mathrm{pH}$

Biological solid wastes such as kitchen refuse and waste from the food industry have been treated by incineration and in landfills in many countries including Japan. Although burning of biological waste materials reduces the volume and stabilizes waste, many problems with this process have been recognized recently. For example, harmful chemicals such as dioxin-related compounds are released. Incineration facilities can also be quickly damaged by temperature fluctuations after semi-continuous addition of kitchen refuse with a high water content, and the incineration process requires supplemental fuel to evaporate the water from biological material. Treatment of biological solid wastes via microbiological processes leads to the improvement of these wastes, and recycling reduces the need for landfill sites, fuel for incineration, and $\mathrm{CO}_{2}$ emission. Aerobic biological treatment stabilizes wastes and can generate compost to fertilize soil. Anaerobic biological treatment has been used for wastewater treatment and offers an effective means of degrading the residual activated sludge, with the concurrent production of a fuel, methane. Although methane fermentation is an excellent method for converting biological solid wastes to by-product resources, the process is slow and requires large facilities.

Lactic acid has both hydroxyl and carboxyl groups with one chiral carbon in its molecule and is widely used not only in the food and pharmaceutical industries but also in the general chemical industry. It is produced via chemical synthesis or via fermentation of agricultural products using various kinds of bacteria or molds (Litchfield, 1996). Lactic acid can be polymerized to form biodegradable polyester, polylactic acid, and is considered a potential substitute for plastics manufactured from petroleum. Systematic lactic acid production, therefore, may be an advanta-

E-mail: sakai@cc.oita-u.ac.jp. geous strategy for the treatment and utilization of waste from the food industry, municipal solid waste, and residual activated sludge. Many studies of lactic acid production from wastes have been reported, including that from molasses (Kanwar et al., 1995), bakery waste (Oda et al., 1997), waste waterpaper (Schmidt \& Padukone, 1997), municipal solid waste (Zhou et al., 1996), and sugar-cane pressmud (Xavier \& Lonsane, 1994).

However, these studies were carried out using pure culture of a lactic acid bacterium.

In attempting to develop an economical process for transforming the biological solid wastes, the authors found that certain amounts of lactic acid were produced from kitchen refuse without any sterilization. Interestingly, intermittent $\mathrm{pH}$ neutralization ( $\mathrm{pH}$ swing) was effective for the stable lactic acid accumulation under open conditions. In this study we investigated the effect of intermittent $\mathrm{pH}$ control on the accumulation of lactic acid during open fermentation of model kitchen refuse (MKR). The change in microbial population during the fermentation was also evaluated.

\section{Materials and Methods}

Fermentation of model kitchen refuse The MKR, which was originally designed by Sankai (1999) considering data from several reports, was used with slight modification: it contained $14 \%(\mathrm{w} / \mathrm{w})$ cooked meat, $40 \%(\mathrm{w} / \mathrm{w})$ vegetables (peel of carrot, potato, and Chinese radish), 30\% (w/w) fruits (apple, banana, and orange peel), $10 \%(\mathrm{w} / \mathrm{w})$ cooked rice, and $6 \%(\mathrm{w} / \mathrm{w})$ green tea residue. Composition of the model kitchen refuse is estimated to be as follows from Standard Tables of Food Composition (Kagawa, 1991): $80 \%$ water, $12 \%$ sugar, $5.6 \%$ protein, $1.8 \%$ fat, $0.3 \%$ fiber, and $0.8 \%$ ash. MKR was minced thoroughly with an equal amount of tap water, stored at $-20^{\circ} \mathrm{C}$ and autoclaved 
before use $\left(120^{\circ} \mathrm{C}, 15 \mathrm{~min}\right)$ to obtain reproducible results using materials from different preparations (MKR paste, $\mathrm{pH}$ 6.0). For seed culture, the minced kitchen refuse was divided into small aliquots, stored at $-20^{\circ} \mathrm{C}$, and was used without sterilization. The autoclaved MKR paste $(30 \mathrm{ml}$ in a $50 \mathrm{ml}$ capped-centrifuge tube) was inoculated with $3 \mathrm{ml}$ of seed culture (non-sterilized MKR paste) and statically incubated at $37^{\circ} \mathrm{C}$. The culture $\mathrm{pH}$ was intermittently monitored and adjusted to appropriate $\mathrm{pH}$ using $10 \mathrm{~N} \mathrm{NaOH}$ or $10 \mathrm{~N} \mathrm{HCl}$, mixing manually with a glass stick, unless otherwise stated. All procedures except for MKR paste preparation were done without any sterilization (open condition).

Viable cell count and isolation of lactic acid bacteria All media were purchased from Nissui Pharmaceutical, Tokyo, and were cultured at $37^{\circ} \mathrm{C}$ for $1-2$ days, unless otherwise stated. The number of total bacterial cells was estimated by pour-plate method, culturing the saline-diluted sample statically in standard method agar. The cell number of lactic acid bacteria was estimated by pour plate method in plate count agar with bromocresol purple. The number of yeast cells was estimated using Potato Dextrose Agar with $0.1 \mathrm{~g} / \mathrm{l}$ chloramphenicol. To estimate the cell number of Escherichia coli and related species (coliform bacteria), deoxycholate agar was used. The plates were incubated anaerobically (BBL GasPak Anaerobic System, Becton Dickinson). The number of clostridial cells was estimated by incubating the plates anaerobically using clostridia count agar.

To isolate microorganisms from the fermented product, colonies appearing in standard method agar were randomly transferred onto another standard method agar plate and incubated for a further 1-2 days anaerobically. DeMan Rogosa Sharpe (MRS) agar (Atlas, 1993) was also used for the separation of lactic acid bacteria, by incubating aerobically or anaerobically.

Identification of the isolated bacteria The isolated bacterial strains were initially classified by their morphological and physiological properties (Kandler \& Weiss, 1989). The medium for investigating cultural properties of isolated bacteria contained $20 \mathrm{~g}$ glucose, $10 \mathrm{~g}$ peptone, $8 \mathrm{~g}$ meat extract, $4 \mathrm{~g}$ yeast extract, 2 $\mathrm{g} \mathrm{KH}_{2} \mathrm{PO}_{4}, 0.2 \mathrm{~g} \mathrm{MgSO}_{4} \cdot 7 \mathrm{H}_{2} \mathrm{O}, 0.05 \mathrm{~g} \mathrm{MnSO}_{4} \cdot 4 \mathrm{H}_{2} \mathrm{O}$, and $20 \mathrm{ml}$ of kitchen refuge extract per liter ( $\mathrm{pH} 7.0$, GK medium). The kitchen refuge extract, adjusted to $\mathrm{pH} 7.0$, was prepared from the supernatant of minced model kitchen refuge that had been autoclaved with an equal volume of tap water at $120^{\circ} \mathrm{C}$ for $20 \mathrm{~min}$, and centrifuged at $10,000 \mathrm{~g}$ for $20 \mathrm{~min}$.

Sugar assimilation patterns of the isolated lactic acid bacteria were analyzed using an API $50 \mathrm{CHL}$ identification kit (bioMerieux, France). For further identification, partial sequences of the $16 \mathrm{~S}$ ribosomal RNA gene (16S rDNA) were analyzed: partial 16S rDNA (ca $1.3 \mathrm{kbp}$ fragment) was amplified using $5^{\prime}$ TAACACATGCAAGTCGA-3' and 5'-GGGAACTTATTCACCG-3' as primers (Marchesi et al., 1998). The DNA sequence was determined using an automatic DNA sequencer ABI 310 (Perkin-Elmer Japan, Tokyo). Phylogenetic relationships were analyzed using Clustal W (Talkington, et al., 1981), using databases from the Ribosomal Database Project (http://rdp.life.uiuc. edu) (Thompson et al., 1994) and Genbank (http://www.ncbi. nlm.nih.gov) (Benson et al., 1998).

Chemical analysis Organic acids (formic acid, acetic acid, propionic acid, lactic acid, and butyric acid) in the supernatant of fermented samples $(2,200 \times g, 20 \mathrm{~min})$ were analyzed using an organic acid analysis system (Shimadzu, Tokyo): solvent delivery system, LC-10AD; column, Shim-pak SCR-102H; detector, CDD-6A; mobile phase, $5 \mathrm{~mm}$ p-toluenesulfonic acid; reaction mixture, $20 \mathrm{~mm}$ Bis-Tris containing $5 \mathrm{~mm}$-toluenesulfonic acid and $100 \mu \mathrm{M}$ EDTA, $40^{\circ} \mathrm{C}$. Selective accumulation of lactic acid was defined as the ratio of lactic acid concentration to the concentration of total organic acids (expressed as a percentage). Productivity was defined as the increase of concentration in the supernatant of the fermenting material per hour $(\mathrm{g} / \mathrm{l} \cdot \mathrm{h})$. Ethanol in the supernatant was analyzed by HPLC (Shimadzu LC-10Ai): column, Shodex Asahipak NH2P-504A (Showa Denko, Tokyo); detection, refractive index (Shimadzu RID-10A); mobile phase, water; room temperature. Optical isomers of lactic acid were analyzed using D- and L-specific lactate dehydrogenase (Boehringer Mannheim, Indianapolis, IN), according to the recommended protocol.

\section{Results}

Effect of $p H$ adjustment on open fermentation of kitchen refuse In preliminary experiments, it was found that a certain amount of lactic acid was produced when non-sterilized kitchen refuse minced with tap water was incubated at $37^{\circ} \mathrm{C}$ without any other regulation. To achieve higher and more selective production of lactic acid, the effect of $\mathrm{pH}$ adjustment on the open fermentation of MKR paste was investigated. As shown in Table 1 (Run 1-1-1-5), the amount of accumulated lactic acid varied according to the intervals of $\mathrm{pH}$ adjustment, and the maximum accumulation was observed with $\mathrm{pH}$ adjustment intervals of $6 \mathrm{~h}$ or $12 \mathrm{~h}$. Shorter intervals led to higher lactic acid productivity. The selective accumulation of lactic acid was over $90 \%$ when the $\mathrm{pH}$ was intermittently adjusted. It should be noted that when the $\mathrm{pH}$ was continuously adjusted to 7.0 using an online- $\mathrm{pH}$ monitor system (Run 1-1), lactic acid accumulated temporarily (19 g/l, after $36 \mathrm{~h}$ ) but was labile and decreased rapidly, resulting in malofermentation with an unpleasant smell.

When the initial and adjusted $\mathrm{pH}$ of the minced kitchen refuse was varied, lactic acid accumulation was most abundant at $\mathrm{pH}$ 7.0 or 10.0 (Table 1, Run 2-6-2-9); however, lactic acid productivity was slightly higher at $\mathrm{pH} 7.0$ than at $\mathrm{pH}$ 10.0. No fermentation occurred when initial $\mathrm{pH}$ was 3.0.

Table 1. Effect of intermittent $\mathrm{pH}$ adjustment on accumulation of lactic acid during the open fermentation of MKR paste.

\begin{tabular}{cccccc}
\hline Run $^{(s)}$ & $\begin{array}{c}\text { adjusted } \\
\mathrm{pH}\end{array}$ & $\begin{array}{c}\text { Interval } \\
(\mathrm{h})^{b /}\end{array}$ & $\begin{array}{c}\text { Productivity } \\
(\mathrm{g} / l \cdot \mathrm{h})^{c)}\end{array}$ & $\begin{array}{c}\text { Accumulation } \\
(\mathrm{g} / l)^{d)}\end{array}$ & $\begin{array}{c}\text { Selectivity } \\
(\%)^{e)}\end{array}$ \\
\hline $1-1$ & 7 & 0 & 1.05 & 19 & 83 \\
$1-2$ & 7 & 6 & 0.70 & 44 & 92 \\
$1-3$ & 7 & 12 & 0.58 & 45 & 94 \\
$1-4$ & 7 & 24 & 0.40 & 31 & 94 \\
$1-5$ & 7 & -6 & 0.25 & 13 & 87 \\
$2-6$ & 3 & $-3)$ & 0.04 & 2.0 & - \\
$2-7$ & 5 & 6 & 0.42 & 32 & 96 \\
$2-8$ & 7 & 6 & 0.65 & 45 & 94 \\
$2-9$ & 10 & 6 & 0.58 & 45 & 92 \\
\hline
\end{tabular}

a) MKR samples of runs 1-1-1-5 and runs 2-6-2-9 were differently prepared

b) Interval of intermittent $\mathrm{pH}$ adjustment.

c)Average production rate of lactic acid to reach maximum concentration.

${ }^{d)}$ Maximum concentration of lactic acid accumulated.

${ }^{e}$ Ratio of accumulation of lactic acid to total organic acids.

${ }^{f} \mathrm{MKR}$ paste was adjusted at $\mathrm{pH} 7.0$ initially and incubated without $\mathrm{pH}$ adjustment.

${ }_{\text {g) }}$ No $\mathrm{pH}$ change was observed. 
Time course of open fermentation of model kitchen refuse To examine the fermentation process in detail, changes in concentrations of organic acids and the microbial populations were investigated. Figure 1 shows a typical time course for fermentation with a $6 \mathrm{~h}$ interval of adjustment to $\mathrm{pH} 7.0$, although the maximum concentration of lactic acid accumulated in this case was lower than those shown in Table 1. After several hours of lag, the concentration of lactic acid increased rapidly and reached $22 \mathrm{~g} / \mathrm{l}$ after $60 \mathrm{~h}$ of incubation. The lactic acid productivity was highest at 12-48 h, and once accumulated, lactic acid was constant even after $120 \mathrm{~h}(27 \mathrm{~g} / l)$. Ethanol was detected after $24 \mathrm{~h}$, and accumulated to a stable $5 \mathrm{~g} / \mathrm{l}$ after $120 \mathrm{~h}$. Acetic acid accumulated after $12 \mathrm{~h}$ incubation and reached maximum at $36 \mathrm{~h}$ $(2.4 \mathrm{~g} / \mathrm{l})$. Only a small amount of propionic acid was found, and no significant amount of formic acid or butyric acid was observed.

The number of total bacterial cells $\left(2 \times 10^{5} \mathrm{cfu} / \mathrm{ml}\right.$ initially) increased rapidly to $3 \times 10^{8} \mathrm{cfu} / \mathrm{ml}$ after $12 \mathrm{~h}$. During the 24 $120 \mathrm{~h}$ interval, the number was maintained at more than $10^{9} \mathrm{cfu} /$ $\mathrm{ml}$. The number of lactic acid bacteria (initially $10^{3} \mathrm{cfu} / \mathrm{ml}$ ) gradually increased to reach an equivalent cell number to the total bacteria after $24 \mathrm{~h}$, and remained at more than $10^{9} \mathrm{cfu} / \mathrm{ml}$ even

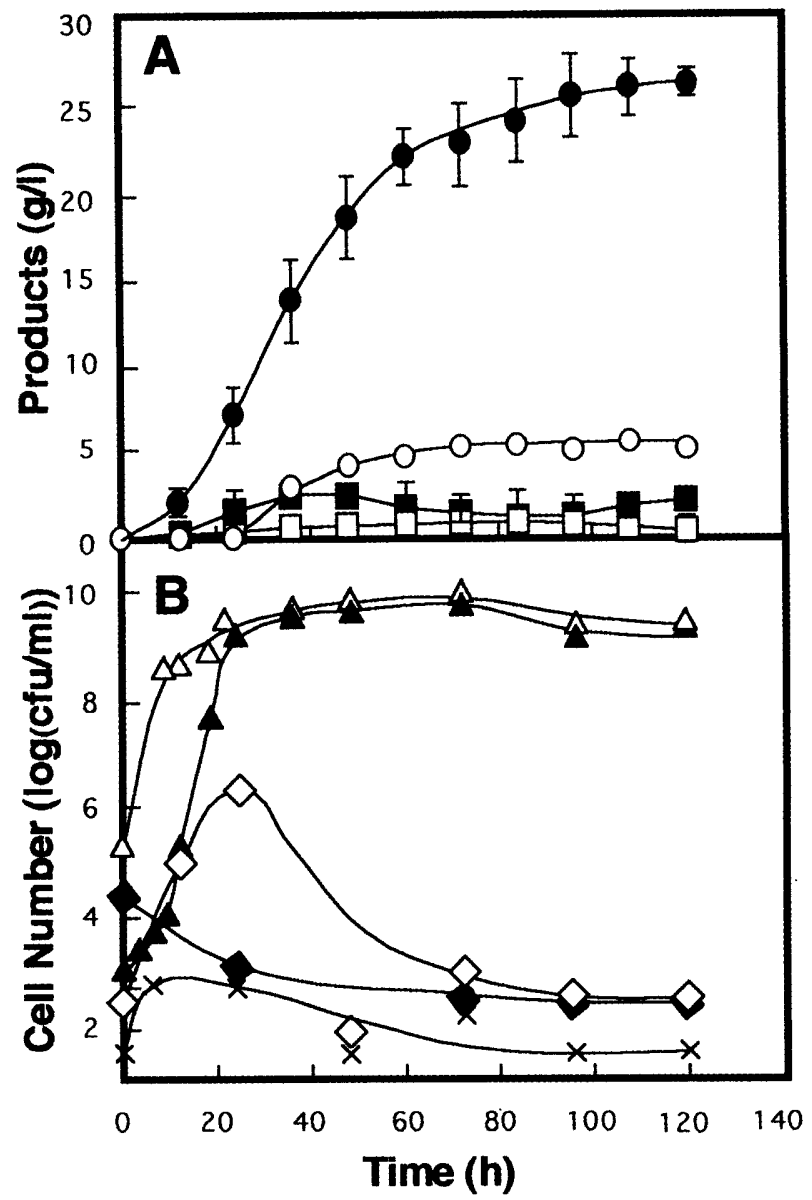

Fig. 1. Typical time course for open fermentation of MKR paste. MKR paste was incubated with the seed culture at $37^{\circ} \mathrm{C}$ statically, and the $\mathrm{pH}$ was adjusted to 7.0 once each $12 \mathrm{~h}$ interval. Concentrations of lactic acid (•), acetic acid ( $\square$ ), propionic acid $(\square)$, or ethanol $(0)$ are shown in A. No meaningful amount of butyric acid, formic acid, or methanol was detected throughout the fermentation. Number of total viable cells $(\triangle)$, LAB $(\Delta)$, coliform bacteria $(\diamond)$, clostridia $(\diamond)$, and yeast $(x)$ is shown in $B$. after $120 \mathrm{~h}$. The number of coliform bacteria increased slightly during the first $24 \mathrm{~h}$ but decreased thereafter. The number of clostridia, initially estimated at $2 \times 10^{4} \mathrm{cfu} / \mathrm{ml}$, decreased over the incubation period, and the number of yeast cells was quite low throughout the fermentation. Table 2 shows the effect of continuous $\mathrm{pH}$ adjustment on open fermentation of MKR paste. Compared to intermittent $\mathrm{pH}$ adjustment, continuous $\mathrm{pH}$ adjust-

Table 2. Effect of continuous $\mathrm{pH}$ adjustment on open fermentation of MKR paste. ${ }^{a}$

\begin{tabular}{lcc}
\hline & Continuous pH adjustment & $\begin{array}{c}\text { Intermittent } \mathrm{pH} \\
\text { adjustment }\end{array}$ \\
\hline Organic acids accumulated $(\mathrm{g} / l)$ & 1.3 & 0 \\
$\quad$ Formic acid & 3.5 & 2.4 \\
Acetic acid & 1.5 & 0.3 \\
Propionic acid & 32 & 27 \\
Lactic acid & 4.2 & 0 \\
Butyric acid & 73 & 91 \\
Selectivity $(\%)^{b)}$ & & $4 \times 10^{9}$ \\
Cell number $(\mathrm{cfu} / \mathrm{ml})$ & $2 \times 10^{9}$ & $3 \times 10^{9}$ \\
Total bacteria & $8 \times 10^{8}$ & $5 \times 10^{2}$ \\
Lactic acid bacteria & $8 \times 10^{3}$ & $4 \times 10^{2}$ \\
Coliform bacteria & $3 \times 10^{6}$ & \\
Clostridia & &
\end{tabular}

${ }^{a}$ Organic acids and cell numbers were analyzed of total bacteria, lactic acid bacteria, coliform bacteria, and clostridia in the sample fermented with continuous $\mathrm{pH}$ adjustment $(\mathrm{pH} 7.0,144 \mathrm{~h}$ ) and with intermittent $\mathrm{pH}$ adjustment ( $\mathrm{pH} 7.0,6 \mathrm{~h}$ interval, $120 \mathrm{~h}$ ).

${ }^{b}$ Ratio of accumulation of lactic acid to total organic acids

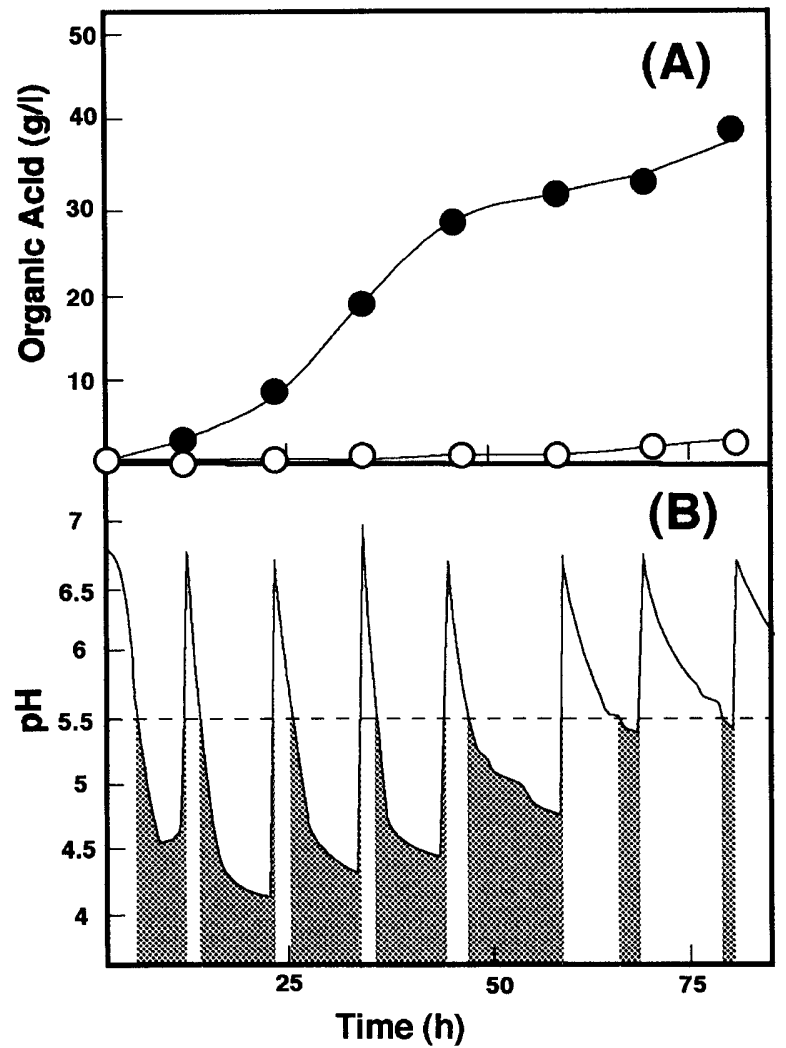

Fig. 2. Change in $\mathrm{pH}$ and organic acid amount during the open fermentation of MKR paste with intermittent $\mathrm{pH}$ adjustment. Experimental conditions are the same as in Fig. 1, and change in $\mathrm{pH}$ of the MKR paste was monitored continuously using a pH meter. A: amounts of lactic acid (•) and acetic acid $(0)$ accumulated. $\mathrm{B}$ : change in $\mathrm{pH}$, shaded area shows the period less than pH5.5. 
ment produced relatively higher amounts of formic acid, propionic acid, and butyric acid, with lower selectivity of lactic acid, making the odor much worse. Higher numbers of coliform bacteria and clostridia were detected under continuous $\mathrm{pH}$ control than under intermittent $\mathrm{pH}$ control. Under continuous $\mathrm{pH}$ control, clostridia grew fast, reached more than $10^{6} \mathrm{cfu} / \mathrm{ml}$ and maintained this number throughout the incubation period (data not shown).

The change in $\mathrm{pH}$ during the fermentation with intermittent pH adjustment ( $12 \mathrm{~h}$ interval) was monitored (Fig. 2). In the first interval, the culture $\mathrm{pH}$ decreased to 4.5 after $6 \mathrm{~h}$, but it took only $3 \mathrm{~h}$ to reach $\mathrm{pH} 4.5$ in the $3 \mathrm{rd}$ interval. As a result, the culture system was below $\mathrm{pH} 5.5$ for $78 \%$ of the total incubation time. The concentration of lactic acid reached $39 \mathrm{~g} / \mathrm{l}$ after $78 \mathrm{~h}$ in this case. These results indicated that intermittent $\mathrm{pH}$ adjustment caused $\mathrm{pH}$ swings in an acidic range, which is effective in repressing the malofermentation of MKR paste.

Identification of dominant bacteria To identify the microorganisms involved in the fermentation, 29 colonies on standard method agar plate were randomly picked from $72 \mathrm{~h}$ fermented MKR paste ( $\mathrm{pH} 7.0,6 \mathrm{~h}$ interval of $\mathrm{pH}$ adjustment). All isolated strains were Gram-positive, non-motile, non-spore forming, catalase negative rods, and accumulated lactate as a main organic acid in GK medium. They grew on MRS agar aerobically. These results suggested that all of these strains belong to Lactobacillus or a related genus. Among them, 14 strains (48\% of the total isolates) showed an identical pattern of sugar assimilation: they fermented various kinds of sugars including D-galactose, D-fructose, D-mannose, L-rhamnose, L-arabinose, D-ribose, N-acetyl-D-glucosamine, maltose, sucrose, cellobiose, lactose, and raffinose. One strain $(\mathrm{KY}-1)$ had a cell size of $1.4-3.8 \times 0.7 \mu \mathrm{m}$, and grew at $15^{\circ} \mathrm{C}$ but not at $45^{\circ} \mathrm{C}$ (Table 3). KY-1 produced L-lactic acid and D-lactic acid in the molar ratio of $78: 22$ in GK medium without any other organic acids, and the yield from glucose was $88 \%$. These results suggested the 14 strains, including strain KY1 , were $L$. plantarum. Identification was confirmed by analyzing the partial sequence of amplified $16 \mathrm{~S}$ rDNA (529 bps). The

Table 3. Some properties of strains KY-1 and KY-2.

\begin{tabular}{|c|c|c|}
\hline & Strain KY-1 & Strain KY-2 \\
\hline Cell shape & rods & rods \\
\hline Cell size $(\mu \mathrm{m})$ & $1.4-3.6 \times 0.7$ & $2.0-3.2 \times 0.7$ \\
\hline Spore formation & - & - \\
\hline Gram-stain & + & + \\
\hline Motility & - & - \\
\hline Catalase activity & - & - \\
\hline $\begin{array}{r}\text { Growth on MRS agar } \\
\text { aerobically } \\
\text { anaerobically }\end{array}$ & $\begin{array}{l}+ \\
+\end{array}$ & $\begin{array}{l}+ \\
+\end{array}$ \\
\hline Products from glucose & D, L-lactic acid & L-lactic acid, ethanol \\
\hline Growth at $15^{\circ} \mathrm{C}$ & + & + \\
\hline $45^{\circ} \mathrm{C}$ & - & - \\
\hline Sugar assimilation & $\begin{array}{l}\text { D-glucose, D-galactose, } \\
\text { D-fructose, D-mannose, } \\
\text { D-turanose, L-rhamnose, } \\
\text { L-arabinose, D-ribose, } \\
\text { N-acetyl-D-glucosamine, } \\
\alpha \text {-methylmannoside, } \\
\text { amygdalin, arbutin, esculin, } \\
\text { salicin, maltose, sucrose, } \\
\text { trehalose, cellobiose, } \\
\text { gentiobiose, lactose, } \\
\text { melezitose, raffinose }\end{array}$ & $\begin{array}{l}\text { D-glucose, D-fructose, } \\
\text { D-xylose, } \\
\text { L-arabinose, } \\
\text { D-ribose, N-acetyl-D- } \\
\text { glucosamine, } \\
\text { maltose, cellobiose, } \\
\text { melibiose, raffinose, } \\
\text { mannitol, gluconate, } \\
\text { 5-keto-gluconate }\end{array}$ \\
\hline
\end{tabular}

rDNA results indicated the nearest neighbor of KY-1 is L. plantarum ATCC 8014 (Genbank accession No. M58827, 99\% homology). Another 11 strains (38\% of the total isolates) showed identical sugar-assimilation patterns, and one of these isolated strains, KY-2, had a cell size of 2.0-3.2 $\times 0.7 \mu \mathrm{m}$, and grew at $15^{\circ} \mathrm{C}$ but not at $45^{\circ} \mathrm{C}$ (Table 3). KY-2 fermented glucose to L-lactic acid, D-lactic acid and ethanol in the molar ratio of $84: 16: 93$. These results suggested the 11 strains including KY2 were $L$. brevis. The highest similarity of partial $16 \mathrm{~S}$ rDNA sequence of strain KY-2 (352 bp) was found in L. brevis ATCC 14869 (Genbank accession No.M58810, 99\% homology), supporting these results. Other strains were identified as $L$. pracase subsp. paracasei (2 strains), L. delbueckii subsp. lactis (1 strain), and L. fermentum (1 strain), from their cell morphologies and sugar-assimilation patterns.

Cultural properties of isolated strains Some cultural properties of $L$. plantarum KY-1 and $L$. brevis KY-2 were examined and compared with those of $E$. coli IFO 3301, using GK mediuum. L. plantarum KY-1 showed good growth over a $\mathrm{pH}$ range from 4.5 to 9.5 (Fig. 3). L. brevis $\mathrm{KY}-2$ grew at $\mathrm{pH} 4.0$ 8.5 , but good growth was observed over a narrower $\mathrm{pH}$ range (4.5-6.0) compared to L. plantarum $K Y-1$. On the other hand, $E$. coli preferred alkaline conditions and showed quite poor growth below $\mathrm{pH}$ 5.5. Lactic acid production by L. plantarum KY-1 in GK medium was $0.66,0.54$, and $0.26(\mathrm{~g} / \mathrm{l} \cdot \mathrm{h})$, and L. brevis $\mathrm{KY}-2$ produced $0.069,0.057$, and $0.024(\mathrm{~g} / \mathrm{l} \cdot \mathrm{h})$ at $\mathrm{pH} 7.0,5.5$, and 4.5 , respectively. When lactic acid $(10 \mathrm{~g} / l)$ was added to the medium, growth of L. plantarum KY-1 and L. brevis KY-2 was repressed at $\mathrm{pH} 4.0$, but not at $\mathrm{pH} 5.5$ or 7.0 . For E. coli, lactic acid stimulated growth at $\mathrm{pH} 7.0$ and 5.5 but no growth was observed at $\mathrm{pH}$ 4.0 , with or without addition of lactic acid. The effect of acetic acid $(5 \mathrm{~g} / l)$ and butyric acid $(2 \mathrm{~g} / l)$ on the growth at $\mathrm{pH} 5.5$ was also investigated. Acetic acid stimulated growth of L. plantarum KY-1 (130\%, relative to that without any additive) and L. brevis KY-2 $(360 \%)$, but slightly inhibited that of E. coli $(80 \%)$. Growth of L. plantarum KY-1 and L. brevis KY-2 was also stimulated by butyric acid (135\% and $950 \%$, respectively), while that of $E$. coli was inhibited (40\%). Addition of kitchen refuse extract

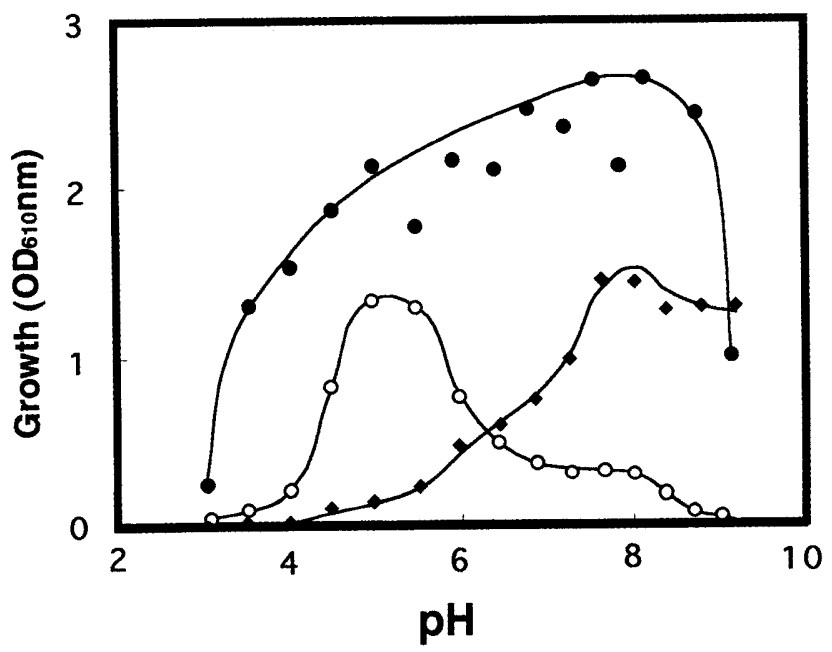

Fig. 3. Effect of $\mathrm{pH}$ on the growth of isolated lactic acid bacteria and $E$. coli. L. plantarum KY-1 $(\bullet)$, L. brevis KY-2 (O), and E. coli IFO $3301(\bullet)$ were cultured in GK medium with various $\mathrm{pH}$ at $37^{\circ} \mathrm{C}$ for $24 \mathrm{~h}$ statically, and their turbidity was measured at $610 \mathrm{~nm}$. 
$(0.1 \%(\mathrm{v} / \mathrm{v}))$ significantly stimulated the growth of $L$. brevis. KY2 , by 25 -fold at $\mathrm{pH} 7.0$ and by 2.3 -fold at $\mathrm{pH} 5.5$. The growth of L. plantarum KY-1 was not affected by the addition of kitchen refuse extract.

\section{Discussion}

In this report, the authors demonstrate that a certain amount of lactic acid is stably accumulated from the minced model kitchen refuse (MKR paste) that has been incubated and intermittently $\mathrm{pH}$ neutralized. Selective accumulation of lactic acid was reproduced in dozens of different experiments, in spite of the open system and variation of the refuse preparation. There have been many studies on lactic acid fermentation of traditional foods (Kodama \& Kumagai, 1997) and forage (Cai et al., 1998) in a simple open system. But there have been few studies on the production of lactic acid in an open system using naturally-inhabiting microorganisms: D'addario et al. (1996) attempted to produce lactic acid from municipal solid waste under an open condition, but with little information.

This study has also shown that reproducible fermentation was made possible by the superior proliferation of lactic acid bacteria originally existing in the model kitchen refuse and maintained in the seed culture. Although the initial number of lactic acid bacteria was only $0.5 \%$ of the total bacteria, they became dominant after lag of a half day (Fig.1). Analysis of the lactic acid bacteria sugar-assimilation patterns, 16S rDNA partial sequence and cell morphology revealed that the predominant LAB types in the fermented MKR paste were $L$. plantarum and L. brevis. Both strains are common in nature and can be found in natural fermentation products such as silage, sauerkraut, cheese, sausage, etc. (Kandler \& Weiss, 1989). L. plantarum is recommended as a starter culture in many cases for fermentation control of silage (Saucedo et al., 1990) and food (Vaugen, 1985). L. brevis is heterofermentative and might be involved in the accumulation of ethanol in MKR paste. In addition, the value of optical activity of accumulated $\mathrm{L}(+)$-lactic acid $(67 \%)$ was explicable from the microbial population. The open fermentation of MKR paste yielded lactic acid at relatively high concentration (42\% of total organic carbon in kitchen refuse at the highest), although the two major isolates showed no assimilation of the major carbon sources in kitchen refuse, starch or cellulose. This suggests the importance of the mixed culture system: some other microorganisms in the MKR might contribute to hydrolysis of polysaccharides, and the consortium in the seed culture might be constructed with some synergistic and commensurate relationships. It would be interesting to investigate the microflora in the early stage of fermentation, where a number of non-LAB could be found (Fig.1).

The ability of $L$. plantarum $\mathrm{KY}-1$ to grow over a wide $\mathrm{pH}$ range and the ability of $L$. brevis $\mathrm{KY}-2$ to grow in the acidic range seemed a likely reason for their superiority in the fermented MKR paste. Without $\mathrm{pH}$ adjustment, growth of these lactic acid bacteria as well as their productivity was slightly repressed. With continuous $\mathrm{pH}$ neutralization, various kinds of microorganisms grew, including clostridia. In this system, the accumulated lactic acid was labile, causing malofermentation. With intermittent $\mathrm{pH}$ neutralization, the fermentation system was periodically and momentary exposed to $\mathrm{pH} 7.0$, but the $\mathrm{pH}$ decreased rapidly from the weak buffer action of MKR paste.
Thus, the microorganisms in the MKR paste were exposed to acidic conditions for most of the fermentation period (Fig.2). This might explain why the fermentation was reproducible, and lactic acid, once produced, accumulated in a stable manner. Consequently, the $\mathrm{pH}$ swings from intermittent adjustment might be effective both for higher productivity of lactic acid and for growth inhibition of non-lactic acid bacteria.

There are many problems to be solved before putting the open fermentation described in this study to practical use. These include reproducibility problems caused by the variable composition of kitchen refuse, lactic acid extraction problems caused by the complexity of fermentation products, and problems relating to the production of low optical activity of lactic acid, which is disadvantageous to the production of fine chemicals. About $17 \%$ of MKR paste (50\% of total carbon) still remained as the fermented residue after fluid was recovered as the crude lactate solution. In spite of this, fermentation of kitchen refuse by such an open system is not only a simple and low cost method for lactic acid production, but is also advantageous as a waste treatment. Collection and disposal of kitchen refuse is often a nasty process due to its unpleasant odor and unsanitary conditions. Increasing the concentration of lactic acid, as well as decrease in $\mathrm{pH}$ has been effective in improving odor by preventing the production of butyric acid, ammonia, and hydrogen sulfide(Olsen et al., 1992). In addition, growth of spoilage (Deshmukh \& Patterson, 1997) or pathogenic microorganisms (Masuda et al. 1998, Okereke \& Montiville, 1991, Talkington et al., 1981) might also be prevented. Lactic acid bacteria occur widely as indigenous contaminants in a variety of raw or minimally processed foods (Kandler \& Weiss, 1989). We found that a variety of unsterilized waste materials from the practical field, were sufficient substrates for lactic acid production (data not shown). Such variation and flexibility in the fermentation will be reported elsewhere.

Acknowledgements This work was supported in part by a Grant-in-Aid for Scientific Research (No. 09450306) from the Ministry of Education, Science Sports, and Culture of Japan, and by Special Coordination Funds for Promoting Science and Technology from the Science and Technology Agency of the Japanese Government.

\section{References}

Atlas, R.M. (1993). "Handbook of Microbiological Media," ed. by L.C. Parks. CRC Press.

Benson, D.A., Boguski, M.S., Lipman, D.J., Ostell, J. and Quellette, B.F. (1998). Genbank. Nucleic Acids Res., 26, 1-7.

Cai, Y., Benno, Y., Ogawa, M., Ohmomo, S., Kumai, S. and Nakase, T. (1998). Influence of Lactobacillus spp. from an inoculant and Weissella and Leuconostoc spp. from forage crops on silage fermentation. Appl. Environ. Microbiol., 64, 2982-2987.

D'addario, E., Fascetti, E. and Valdisseri, M. (1996). Hydrogen production from organic waste by continuous culture of Rhodobacter sphaeroides RV. Proceedings of the 11th World Hydrogen Energy Conference, Stuttgart, Germany, pp. 2577-2582.

Deshmukh, A.C. and Patterson, P.H. (1997). Preservation of hatchery waste by lactic acid fermentation. 1. Laboratory scale fermentation. Poultry Sci., 76, 1212-1219.

Kagawa, A. (1991). "Standard Tables of Food Composition in Japan," 4th edition, Kagawa Nutrition University Publisher, Tokyo (in Japanese).

Kandler, O. and Weiss, N. (1989). Section 14. Regular, nonsporing Gram-positive rods. In "Bergey's Manual of Systematic Bacteriology," ed. by P.H.A. Sneath, N.S. Mair, M.E. Sharpe and J.G. Holt. Williams \& Wilkins, vol 2, pp. 1208-1234.

Kanwar, S.S., Tewari, H.K., Chadha, B.S., Punji, V. and Sharma, V.K. 
(1995). Lactic acid production from molasses by Sporolactobacillus cellulosolvens. Acta. Microbiol. Immuno. Hung., 42, 331-338.

Kodama, T. and Kumagai, H. (1997). "Food Microbiology," Bun-eidou Shuppan, Tokyo (in Japanese).

Litchfield, J.H. (1996). Microbiological production of lactic acid. Adv. Appl. Microbiol., 42, 45-95.

Maidak, B.L., Olsen, G.J., Larsen, N., Overbeek, R., McCaughey, M.J. and Woese, C.R. (1997). The RDP (ribosomal database project). Nucleic Acids Res., 25, 109-111.

Marchesi, J.R., Sato, T., Weightman, A.J., Martin, T.A., Fry, J.C., Hiom, S.J. and Wade, W.G. (1998). Design and evaluation of useful bacterium-specific PCR primers that amplify genes coding for bacterial 16S rRNA. Appl. Environ. Microbiol., 64, 795-799.

Masuda, S., Hara-Kudo, Y. and Kumagai, S. (1998). Reduction of Escherichia coli $\mathrm{O} 157$ : $\mathrm{H} 7$ populations in soy sauce, a fermented seasoning. J. Food Protec., 61, 657-661.

Oda, Y., Park, B.S., Moon, K.H. and Tonomura, K. (1997). Recycling of bakery wastes using an amylolytic lactic acid bacterium. Biores. Technol., 60, 101-105.

Okereke, A. and Montiville, T.J. (1991). Bacteriocin-mediated inhibition of Clostridium otulinum spores by lactic acid bacteria at refrigeration and abuse temperatures. Appl. Environ. Microbiol., 57, 3243-3248

Olsen, S.M., Fletcher, D.L. and Merka, W.C. (1992). Lactic acid fermentation of broiler processing waste: Physical properties and chemical analysis. Poultry Sci., 71, 765-770.

Sankai, T. (1999). Development of recycling system of kitchen refuse using disposer. In "Disupoza ni Yoru Namagomi no Shori," ed. by
Foundation of Japan Achitecture Center, pp. 5-15 (in Japanese).

Saucedo, C.G., Gonzalez, P.B., Revah, S.M., Viniegra, G.G. and Raimbault, M. (1990). Effect of lactobacilli inoculation on cassava (Manihot esculenta) silage: Fermentation pattern and kinetic analysis. J. Sci. Food. Agric., 50, 467-477.

Schmidt, S. and Padukone, N. (1997). Production of lactic acid from waste waterpaper as a cellulosic feedstock. J. Indust. Microbiol. Biotechnol., 18, 10-14.

Spelhaug, S.R. and Harlander, S.K. (1989). Inhibition of foodborne bacterial pathogens by bacteriocins from Lactococcus lactis and Pediococcus pentosaceus. J. Food Protec, 52, 856-862.

Talkington, F.D., Shotts, E.B., Wooley, R.E., Whitehead, W.K. and Dobbins, C.N. (1981). Introduction and reisolation of selected Gram-negative bacteria from fermented edible wastes. Am. J. Vet. Res., 42, 1298-1301.

Thompson, J.D., Higgins, D.G. and Gibson, T.J. (1994). CLUSTAL $\mathrm{W}$ : Improving the sensitivity of progressive multiple sequence alignment through sequence weighting, position-specific gap penalties and weight matrix choice. Nucleic Acids Res., 22, 4673-4680.

Vaugen, R.H. (1985). The microbiology of vegetable fermentations. In "Microbiology of fermented foods," ed. by J.B. Wood. Elsevier Applied Scince Publishers, vol 1., pp. 49-109.

Xavier, S. and Lonsane, B.K. (1994). Sugar-cane pressmud as a novel and inexpensive substrate for production of lactic acid in a solidstate fermentation system. Appl. Biochem. Biotechnol., 41, 291-295.

Zhou, S.D., McCaskey, T.A. and Broder, J. (1996). Evaluation of nitrogen supplements for bioconversion of municipal solid waste to lactic acid. Appl. Biochem. Biotechnol., 57/58, 517-524. 